\title{
Andrzej Derdziuk OFMCap W odpowiedzi na dar powotania Wydawnictwo KUL, Lublin 2016, 174 s.
}

W szczególnym roku 1050. Rocznicy Chrztu Polski warto uświadomić sobie, że na mocy łaski chrztu świętego wszyscy jesteśmy powołani do świętości. To zobowiązuje do tego, aby na drodze swojego życiowego powołania nieustannie dążyć do doskonałości i szukać postaw najbardziej godnych dojrzałego chrześcijanina.

W tych poszukiwaniach cenną pomocą może być publikacja ojca prof. dr hab. Andrzeja Derdziuka, wydana przez wydawnictwo KUL pt. W odpowiedzi na dar powołania. Jest ona zapisem rekolekcji wygłoszonych w Lubartowie w maju 2014 roku przed święceniami diakonatu i kapłaństwa dla braci z kapucyńskiego Wyższego Seminarium Duchownego w Lublinie.

Ojciec prof. dr hab. Andrzej Derdziuk, jest członkiem Warszawskiej Prowincji Zakonu Braci Mniejszych Kapucynów. W swoim życiu pełnił wiele odpowiedzialnych funkcji m.in. posługę duszpasterza powołań, magistra wakacyjnego postulatu, mistrza nowicjatu, ojca duchownego seminarium i junioratu oraz wykładowcy w seminarium i junioracie, a także przez dziesięć lat był rektorem Wyższego Seminarium Duchownego Kapucynów w Lublinie. Zakonnik przez kilka lat pełnił funkcję wiceprzewodniczącego Konferencji Rektorów Seminariów Diecezjalnych i Zakonnych w Polsce. Ponadto o. Derdziuk jest wykładowca, spowiednikiem, oraz cenionym rekolekcjonistą, dlatego w kontekście recenzowanej publikacji dla czytelnika może być kierownikiem duchowym, który dzieli się nie tylko wiedzą, ale i bogatym doświadczeniem.

Autor w tych rekolekcjach stałym punktem odniesienia uczynił scenę Zwiastowania opisaną przez św. Łukasza Ewangelistę. Odwołując 
Reports and reviews się w swych rozważaniach do tego wydarzenia ukazał, Maryję jako Gwiazdę przewodnią i wzór do naśladowania. Ona swoim fiat wypowiedzianym podczas Zwiastowania uczy każdego powołanego postawy całkowitego zawierzenia Bogu, który wybiera i uzdalnia do wypełnienia Bożego planu.

Książka zawiera wprowadzenie, dziesięć konferencji i sześć homilii. Pierwsza, zdecydowanie przeważająca część to konferencje, z których każda jest nakreśleniem pewnych uwarunkowań i postaw, jakie moga być pomocne w odpowiedzi na dar powołania.

Pierwsza konferencja Zwiastowanie mojego życia, stanowi wprowadzenie do rekolekcji. Aby był to czas rzeczywistego szukania Boga i przygotowania do życiowego fiat, potrzeba klimatu wyciszenia wewnętrznego i zewnętrznego. Wyciszenie sprzyja duchowej walce, jaką niejednokrotnie powinien stoczyć człowiek, aby doświadczył spotkania z żywym Bogiem. Rekolekcje to swoisty luksus i szansa, aby kształtować swoją oryginalność oraz uszlachetniać serce i umysł, którymi w kapłaństwie Pan Bóg będzie się posługiwał jako narzędziami.

Konferencja druga zatytułowana Historia mojego zbawienia jest zachętą, aby odczytać swoje życie, w kontekście powołania. Na życie osoby powołanej składają się: rodzina, środowisko, w którym żyje, oraz historia, którą tworzy. Spojrzenie na te płaszczyzny w kluczu wiary i zaufania pozwala zauważyć szczególne prowadzenie przez Boga. Ta historia wpisuje się w plan Boży, co z kolei pomaga w odpowiedzialnym wypowiedzeniu fiat, wybierając drogę powołania.

Przymierze z Bogiem w wierze to temat kolejnej konferencji. Najpierw rekolekcjonista odwołuje się do postaci ks. prof. Janusza Nagórnego. Ksiądz Nagórny w toku badań naukowych analizując przymierze na Synaju wyróżnił w nim trzy elementy: prolog, zobowiązanie fundamentalne i kategorialne wskazanie. Te wiadomości autor konferencji odniósł do przymierza, jakie Bóg w scenie Zwiastowania zawarł z Maryją. Jest Ona poprzez nieustannie powtarzane fiat ukazana jako wzór wiary. Autor wnioskuje, że wiara jest postawą całożyciową, obejmująca przeszłość, teraźniejszość i przyszłość, angażującą wszystkie władze człowieka i prowadzi do ostatecznej decyzji, która w przymierzu z Bogiem musi zakończyć się fiat.

Konferencja czwarta Świadomość wybrania przez Boga, to refleksja nad słowami: „Anioł wszedł do Niej i rzekł: «Bądź pozdrowiona, pełna łaski, Pan z Tobą, błogosławiona jesteś między niewiastami»". Autor zauważa, że Bóg wybrał Maryję i nadzwyczaj ubogacił. To pokazuje, że powołanie do służby jest wyrazem Bożego umiłowania. Chcąc na ten dar odpowiedzieć jak Maryja, trzeba mieć świadomość, że obdarowanie 
jest dane w określonym celu, tzn. aby było darem dla innych i wypełnieniem misji zbawiania świata.

Temat następny to Ewangeliczne ubóstwo. Ojciec Derdziuk wskazuje na dwa wymiary ubóstwa w życiu Maryi: pierwszy wynika ze stwierdzenia anavim i wyraża się w postaci całkowitego zawierzenia Bogu własnej przyszłości i tego, co się z nią wiąże. Autor wspomina także o ubóstwie w wymiarze moralnym, które wynika z naszej kruchości, grzeszności i lęku. W dalszej części konferencji zostały w praktyczny sposób przedstawione postawy kapłańskiego ubóstwa. Są nimi: dowartościowanie człowieka biednego, dyspozycyjność, przedsiębiorczość, pomysłowość, troska o dobro wspólne, wykorzystywanie ubogich środków, przejrzystość i sprawiedliwość.

W kolejnej konferencji Czystość Bogu konsekrowana kaznodzieja zwraca uwagę na temat czystości kapłańskiej. Można ją rozważać na dwóch płaszczyznach: motywacji i radzenia sobie ze swoim ciałem. Wśród motywów autor wymienia: świadomość wybrania i powołania do miłości oblubieńczej, przeżywanie czystości jako powołania do ojcostwa oraz dyspozycyjności dla Kościoła. Z kolei na płaszczyźnie zmysłowo-cielesnej należy nauczyć się pokonywać trudności. Dlatego konieczne jest poznanie swojej cielesności, aby umieć radzić sobie z bodźcami, które ją pobudzają. Unikanie okazji do grzechu i doświadczenie przyjaźni, zdaniem autora pomaga, aby dla kapłana czystość była piękna i nie umniejszała poczucia męskości.

W następnym rozważaniu pt. Postuszeństwo w stużbie dobra wspólnego, autor spoglądając na Maryję wnioskuje, że posłuszeństwo konsekrowane jest najlepszym sposobem używania człowieczeństwa i musi wpisywać się w ogólny plan Boży. Jest ono wolnym i ofiarnym zaangażowaniem się aż do kenozy, czyli wyniszczania się w służbie innym. Autor zauważa, że jest to związane z problematyką uczestnictwa, które to zagadnienie było przedmiotem zainteresowania ks. prof. Nagórnego. Ojciec Derdziuk analizuje różne postawy wobec posłuszeństwa, m.in. posłuszeństwo ze strachu. Wskazuje, że w realizowaniu posłuszeństwa może pomóc rozwijanie takich cnót jak: pokora, męstwo, cierpliwość oraz wiara, że wszystko jest po coś.

Przedmiotem następnej konferencji jest Zachwyt $i$ kontemplacja tajemnicy powołania. Pragnienie służby Bogu rozpoczyna się od zdumienia nad objawieniem tajemnicy miłości. Płaszczyzną zachwytu człowieka powołanego jest tajemnica zstąpienia Boga, do którego każdy konsekrowany ma uprzywilejowany dostęp w przestrzeni swojego serca, umysłu i rąk, szczególnie podczas przyjmowania sakramentów, a zwłaszcza Eucharystii. Aby zatem przeżywać zachwyt 
i kontemplować tajemnicę powołania warto czerpać wzór z Matki Najświętszej, tzn. tak jak Ona oddać swoje życie jedynej miłości oraz zapalić się nią, tak, aby spłonąć.

Modlitwa nieustanna jako duchowa mistrzyni braci, to dziewiąta konferencja i zaproszenie, aby powiedzieć Bogu fiat w odniesieniu do modlitwy osobistej. Modlitwa, której źródłem jest Bóg sprawia, że kapłan żyje przed Jego obliczem. Ona wprowadza równowagę, ład i pokój w działanie oraz wykorzystywanie czasu, co wyraźnie widać na przykładzie Maryi.

Ostatnie zamyślenie nosi tytuł Stużyć i żyć stowem Bożym i jest poświęcone tematyce słowa Bożego, które jest duchowym pokarmem powołanego. Autor w tej konferencji podzielił się ze słuchaczami swoim odkrywaniem Pisma Świętego, które obejmowało różne etapy: od zdumienia i zaciekawienia wypływającego z lektury, poprzez znudzenie,

Reports and reviews aż do ponownego zachwytu i radosnego głoszenia. Rekolekcjonista przestrzega także przyszłych głosicieli słowa przed trudnościami, które mogą wyniknąć z lęku, małoduszności lub pychy. Kaznodziejstwo ewangeliczne domaga się pokory mówienia rzeczy prostych, ale opartych na słowie Bożym, co autor zaprezentował w dalszej części książki w kilku homiliach.

Pierwsza homilia zatytułowana Serce jako ottarz ofiarny to refleksja na temat przestrzeni, w której może działać Bóg. Ta przestrzeń znajduje się w głębi ludzkiego serca, gdzie powołany musi powiedzieć Bogu tak. Kapłańskie serce ma być taką przestrzenią, w której ludzie czują się bezpieczni. Kapłan musi zgodzić się na bycie świątynią ducha, ołtarzem, na którym ofiaruje się Bóg.

W kolejnej homilii autor zauważył, że życie powołanego to nie sielanka, ale wezwanie do trwania Wobec sprzeciwu świata, nieprzychylnego chrześcijanom. Jednak pomimo tych trudności warto, rozpalać w sobie zapał ewangelizacyjny i z odwagą dać się prowadzić Duchowi Świętemu.

W trzeciej homilii kaznodzieja ukazał Moc wiary, która urzeczywistnia się na trzech płaszczyznach: wobec Boga, samego siebie oraz drugiego człowieka i świata. Wiara przekracza nasze ludzkie rozumowanie, ale ten, kto odważy się przyjąć Boże orędzie jako prawdziwe, doświadczy mocy Jezusa Zmartwychwstałego i Jego miłości.

Kolejna homilia to zwrócenie uwagi na to, jak wielka jest Siła łagodności. Przy omawianiu tej postawy autor przywołał postać św. Franciszka, który dzięki mocy Ducha Świętego naśladował Jezusa w postawie służby i wrażliwości na drugiego człowieka. Kapłan łagodny i wrażliwy, 
dający swoim życiem świadectwo Ewangelii, jest prawdziwym uczniem Jezusa, zdolnym do tego, aby innych czynić uczniami.

W homilii piątej autor przypomina, że misją kapłana jest Głoszenie prawdy o grzechu i pokucie. Grzech został pokonany przez miłość Jezusa na krzyżu. Dlatego realizowanie powołania powinno być nie tylko pasterzowaniem, ale misjonowaniem, szukaniem trzody i niesieniem jej orędzia o wielkim miłosierdziu Boga.

W ostatniej homilii o. Derdziuk pokazuje że powołani są Prowadzeni przez Ducha Świętego. Duch Święty uczy, aby być skutecznym i owocnym, należy współpracować z innymi. Kiedy powołany otwiera się na działanie Ducha Świętego, staje się zdolnym do tego, aby jak Maryja nieustannie powtarzać: „Fiat - niech mi się stanie według Słowa Twego".

Publikacja W odpowiedzi na dar powołania ukazuje radość ze służby i kroczenia drogą powołania, która się nie wyczerpuje, ale wzywa do dzielenia się nią ze swymi braćmi i siostrami. Wielkim walorem tej książki jest osobiste świadectwo wiary i ukochania kapłaństwa, którym rekolekcjonista dzieli się, z przygotowującymi się do kapłaństwa. Piękny język ubogacony licznymi cytatami, przykładami świętych oraz wieloma odniesieniami do codziennego życia i własnego doświadczenia, a także humorystyczne wtrącenia sprawiają, że jest to lektura ciekawa, oryginalna i wciągająca czytelnika.

Książka została wydana w miękkiej oprawie i bardzo poręcznym formacie. Zamieszczony na okładce fresk Fra Angelico - Zwiastowanie, z klasztoru św. Marka we Florencji zachęca, aby do niej zaglądnąć. W publikacji wyraźnie zostały oddzielone konferencje od homilii. Konferencje i homilie zostały ponumerowane i zawierają czytelne tytuły. Wydaje się, że pomocą w części zawierającej homilie byłoby umieszczenie informacji o siglach biblijnych do tekstów, w oparciu o które zostały przygotowane rozważania. Książka nie zawiera zakończenia, co można odczytać jako zachętę do dalszej refleksji. Jeśli te rekolekcje mają być owocne nie mogą się zakończyć wraz z lekturą, ale przeczytane treści należy przełożyć na życie.

Edycja jest godna polecenia każdemu człowiekowi, który szuka pogłębienia życia duchowego i odpowiedzi na dar powołania. 